\title{
PREVALENCE OF HIV INFECTION AMONG BLOOD DONORS AT TERTIARY CARE TEACHING HOSPITAL OF UTTAR PRADESH
}

\author{
Sarandeep Singh Puri' ${ }^{1}$ P. S. Dhot ${ }^{2}$
}

${ }_{1}^{1}$ Assistant Professor, Department of Pathology, Saraswathi Institute of Medical Sciences, Hapur, Uttar Pradesh.

${ }^{2}$ Professor and HOD, Department of Pathology, Saraswathi Institute of Medical Sciences, Hapur, Uttar Pradesh.

\begin{abstract}
BACKGROUND
ABSTRACT

Blood transfusion is a life-saving measure used in the field of medicine. Transfusion medicine has great public health importance. The screening of transfusion transmitted infections is mandatory in blood donors for the safety of recipient. The National blood transfusion council has recommended voluntary non-remunerated blood donors.

Aim- The present study was done to retrospectively analyse the prevalence of HIV infection in blood donors from November 2009 to November 2017.
\end{abstract}

\section{MATERIALS AND METHODS}

All tests were done using the fourth generation ELISA kit (J Mitra and Co. Pvt. Ltd.), which detected the presence of anti-HIV antibodies.

Settings and Design- The study was carried out in the Blood Bank at Saraswathi Institute of Medical Sciences, Hapur, Uttar Pradesh.

\section{RESULTS}

A total of 6982 blood donors were screened, of which 6881 (98.5\%) were males and 101 (1.44\%) were females. Replacement donations of $6770(96.96 \%)$ represented the majority, whereas only 212 (3.03\%) donations were from the voluntary donors.

\section{CONCLUSION}

Our study showed the prevalence of HIV to be $0.071 \%$ in our tertiary care teaching hospital.

\section{KEYWORDS}

Blood Donor, Transfusion Transmitted Infection, HIV Infection.

HOW TO CITE THIS ARTICLE: Puri SS, Dhot PS. Prevalence of HIV infection among blood donors at tertiary care teaching hospital of Uttar Pradesh. J. Evolution Med. Dent. Sci. 2018;7(12):1513-1515, DOI: 10.14260/jemds/2018/342

\section{BACKGROUND}

The transfusion of blood and its components is the keystone of our health care system. Transmission of HIV and other viral infections is a threat to safe blood transfusion. The enormous medical and social burden of the AIDS problem has led to an explosion of research aimed at understanding HIV and its remarkable ability to cripple host defenses. Blood transfusion can be a significant route of infection. The extent to which blood transfusion is an actual route of transmission depends on the prevalence of infected individuals in the population and on the effectiveness of the screening program used.

According to WHO safe blood is a universal right, which means blood that will not cause any harm to the recipient and that has been fully screened and is not contaminated by any blood-borne disease such as HIV, Hepatitis, Syphilis or Malaria.(1)

Transmission of HIV occurs under conditions that facilitate exchange of blood or body fluids containing the virus or virus-infected cells. Self-exclusion is probably the most effective approach in preventing transmission, but is dependent on the education of potential donors about risk

'Financial or Other Competing Interest': None.

Submission 05-02-2018, Peer Review 02-03-2018,

Acceptance 08-03-2018, Published 19-03-2018.

Corresponding Author:

Dr. Sarandeep Singh Puri,

R-12/72, Raj Nagar, Azed-201001,

Uttar Pradesh.

E-mail: drsarandeep147@gmail.com

DOI: $10.14260 /$ jemds $/ 2018 / 342$

\section{(c) $($ ) $९$}

behaviour. It is particularly important to encourage selfexclusion by people such as prostitutes, homosexual and bisexual men, injecting drug users, those who have any unprotected sexual contact other than with a regular partner and the sexual contacts of any of these people.(2)

Laboratory diagnosis of HIV includes detection of HIV Antigen or anti-HIV antibody or both. The nucleic acid amplification testing has been introduced for blood donor screening. The present retrospective study analysed prevalence of HIV infection in blood donors in the Blood Bank at Saraswathi Institute of Medical Sciences, Hapur, Uttar Pradesh.

\section{MATERIALS AND METHODS}

The retrospective descriptive study included donors who donated blood at the Blood Bank of Saraswathi Institute of Medical Sciences, Hapur, Uttar Pradesh, a medical college situated in northern India. The study was carried out between November 2009 and November 2017. The donors were adults of the age group 18 - 60 years. The donors were either replacement or voluntary. Majority of donors were replacement. The exclusion criterion included paid and commercial donors and those with a history of high-risk behaviour. Consent was obtained from all donors prior to blood donation.

The donor blood samples were collected at the time of blood donation from the primary bag and tested for the presence of HIV using enzyme-linked immunosorbent assay (ELISA). All tests were done using the fourth generation ELISA kit (J Mitra and Co. Pvt. Ltd.), which detected the presence of anti-HIV antibodies. Tests were performed 
according to manufacturer's instructions. All reactive samples were repeated in duplicate as per directions from National AIDS Control Organisation. Repeat reactives were labelled as ELISA positive and were discarded.

\section{RESULTS}

This retrospective descriptive study showed a total of 6982 donors, who donated blood during 2009 - 2017. Replacement donations 6770 (96.96\%) represented the majority, whereas only $212(3.03 \%)$ donations were from the voluntary donors (Table 1).

Among them, 6881 (98.5\%) were male donors and 101 (1.44\%) were female donors (Table 2).

The overall seroprevalence of HIV was found to be 0.071\% (Table 3).

The comparison of HIV seropositivity in different blood donor categories showed seroprevalence of HIV to be higher in replacement donors. None of the blood donors were found to be reactive in voluntary category. HIV seropositivity was $0.073 \%$ in replacement donors (Table 4).

Maximum seroprevalence of HIV infection was seen in the donors in the age group of 18 - 30 yrs. followed by the age category of 31 - 40 yrs. None of the donors in the age groups of 41 - 50 yrs. and 51 - 60 yrs. were found to be seroreactive (Table 5).

Our study analysed higher seropositivity of HIV among male donors. None of the female donors were found to be seroreactive for HIV (Table 6).

Our study analysed demographic distribution of HIV positive blood donors. It was found that higher seropositivity was seen in donors from urban areas (Table 7).

\begin{tabular}{|c|c|c|c|}
\hline Year & $\begin{array}{c}\text { Total Blood } \\
\text { Donors }\end{array}$ & Voluntary & Replacement \\
\hline 2009 & 30 & $07(23.33 \%)$ & $23(76.66 \%)$ \\
\hline 2010 & 677 & $24(3.54 \%)$ & $653(96.45 \%)$ \\
\hline 2011 & 1070 & $30(2.80 \%)$ & $1040(97.19 \%)$ \\
\hline 2012 & 958 & $28(2.92 \%)$ & $930(97.07 \%)$ \\
\hline 2013 & 998 & $27(2.70 \%)$ & $971(97.29 \%)$ \\
\hline 2014 & 872 & $22(2.52 \%)$ & $850(97.47 \%)$ \\
\hline 2015 & 862 & $20(2.32 \%)$ & $842(97.67 \%)$ \\
\hline 2016 & 784 & $24(3.06 \%)$ & $760(96.93 \%)$ \\
\hline 2017 & 731 & $30(4.10 \%)$ & $701(95.89 \%)$ \\
\hline Total & $\mathbf{6 9 8 2}$ & $\mathbf{2 1 2 ( 3 . 0 3 \% )}$ & $\begin{array}{c}\mathbf{6 7 7 0} \\
\mathbf{( 9 6 . 9 6 \% )}\end{array}$ \\
\hline
\end{tabular}

Table 1. Distribution of Blood Donor Categories in SIMS, Hapur (2009 - 2017)

\begin{tabular}{|c|c|c|c|c|c|}
\hline Year & $\begin{array}{c}\text { Total Blood } \\
\text { Donors }\end{array}$ & \multicolumn{2}{|c|}{ Voluntary } & \multicolumn{2}{c|}{ Replacement } \\
\hline & & Male & Female & Male & Female \\
\hline 2009 & 30 & 05 & 02 & 22 & 01 \\
\hline 2010 & 677 & 21 & 03 & 640 & 13 \\
\hline 2011 & 1070 & 29 & 01 & 1030 & 10 \\
\hline 2012 & 958 & 26 & 02 & 921 & 09 \\
\hline 2013 & 998 & 25 & 02 & 960 & 11 \\
\hline 2014 & 872 & 19 & 03 & 840 & 10 \\
\hline 2015 & 862 & 18 & 02 & 831 & 11 \\
\hline 2016 & 784 & 20 & 04 & 753 & 07 \\
\hline 2017 & 731 & 26 & 04 & 695 & 06 \\
\hline Total & $\mathbf{6 9 8 2}$ & $\mathbf{1 8 9}$ & $\mathbf{2 3}$ & $\mathbf{6 6 9 2}$ & $\mathbf{7 8}$ \\
\hline
\end{tabular}

Table 2. Gender Distribution of Blood Donors in SIMS, Hapur (2009 - 2017)

\begin{tabular}{|c|c|c|c|}
\hline Year & $\begin{array}{c}\text { Number of } \\
\text { Donations Tested }\end{array}$ & \multicolumn{2}{c|}{ HIV Positive Cases } \\
\hline & & Number & Prevalence (\%) \\
\hline 2009 & 30 & 0 & 0 \\
\hline 2010 & 677 & 1 & 0.14 \\
\hline 2011 & 1070 & 0 & 0 \\
\hline 2012 & 958 & 0 & 0 \\
\hline 2013 & 998 & 1 & 0.10 \\
\hline 2014 & 872 & 0 & 0 \\
\hline 2015 & 862 & 1 & 0.11 \\
\hline 2016 & 784 & 1 & 0.12 \\
\hline 2017 & 731 & 1 & 0.13 \\
\hline Total & 6982 & 05 & 0.071 \\
\hline \multicolumn{4}{|c|}{$\begin{array}{c}\text { Table 3. Seroprevalence of HIV Infection } \\
\text { in Blood Donors (2009 - 2017) }\end{array}$} \\
\hline
\end{tabular}

\begin{tabular}{|c|c|c|c|}
\hline Year & Replacement (\%) & Voluntary (\%) & Total (\%) \\
\hline 2009 & 0 & 0 & 0 \\
\hline 2010 & $1(0.15)$ & 0 & $1(0.14)$ \\
\hline 2011 & 0 & 0 & 0 \\
\hline 2012 & 0 & 0 & 0 \\
\hline 2013 & $1(0.10)$ & 0 & $1(0.10)$ \\
\hline 2014 & 0 & 0 & 0 \\
\hline 2015 & $1(0.118)$ & 0 & $1(0.116)$ \\
\hline 2016 & $1(0.13)$ & 0 & $1(0.12)$ \\
\hline 2017 & $1(0.14)$ & 0 & $1(0.13)$ \\
\hline Total & 05 (0.073) & 0 & 05 (0.071) \\
\hline Table 4. Number and Percentage of HIV Seropositives in \\
different Blood Donor Categories \\
\hline \multicolumn{4}{|l}{} \\
\hline
\end{tabular}

\begin{tabular}{|c|c|c|}
\hline Age (yr.) & $\begin{array}{c}\text { Total Number of } \\
\text { Donors }\end{array}$ & $\begin{array}{c}\text { Number (\%) of HIV } \\
\text { Seroreactive Donors }\end{array}$ \\
\hline $18-30$ & 3044 & $3(0.09)$ \\
\hline $31-40$ & 2304 & $2(0.08)$ \\
\hline $41-50$ & 1235 & 0 \\
\hline $51-60$ & 399 & 0 \\
\hline \multicolumn{2}{|c|}{ Table 5. Age Distribution of HIV Seroreactive } \\
Donors (2009-2017)
\end{tabular}

\begin{tabular}{|c|c|c|}
\hline & $\begin{array}{c}\text { Total Number } \\
\text { of Donors }\end{array}$ & $\begin{array}{c}\text { Number (\%) of HIV } \\
\text { Seroreactive Donors }\end{array}$ \\
\hline Male Donors & 6881 & $5(0.07)$ \\
\hline Female Donors & 101 & 0 \\
\hline \multicolumn{2}{|c|}{ Table 6. Gender Distribution of HIV Seroreactive } \\
Donors (2009 - 2017) \\
\hline
\end{tabular}

\begin{tabular}{|c|c|c|}
\hline Population & $\begin{array}{c}\text { Total Number } \\
\text { of Donors }\end{array}$ & $\begin{array}{c}\text { Number (\%) of HIV } \\
\text { Seroreactive Donors }\end{array}$ \\
\hline Rural & 5307 & $1(0.01)$ \\
\hline Urban & 1675 & $4(0.23)$ \\
\hline \multicolumn{2}{|c|}{ Table 7. Demographic Distribution of HIV Seroreactive } \\
Donors (2009 - 2017)
\end{tabular}

\section{DISCUSSION}

The majority of donors in the present study were replacement donors (96.66\%) and similar findings have been reported by Singh et al(3) and Kochhar et al,(4) $82.4 \%$ and $96.53 \%$ of their respective donors were replacement donors. The reason for less voluntary donations in our setup is due to lack of awareness, knowledge about health education system and a sense of insensitivity towards health sector in our area. It has been observed that people are afraid to undergo voluntary blood donation in our settings. 
Our study noted that majority of blood donors were males, i.e. $98.5 \%$. One of the reasons for the gender imbalance in blood donation in our areas is males are more proactive and independent in decision making than females would have the opportunity for. Also higher rate of deferrals in females, most frequently because of a low level of haemoglobin and higher rate of adverse reactions in women, which is related to the lower weight of women compared to that of men, which increases the probability of adverse reactions such as dizziness and fainting.(5)

In our study, the prevalence of HIV was found to be $0.071 \%$. Similar findings were reported by Gupta et al(6) and Tiwari et al,(7) $0.084 \%$ and $0.054 \%$ prevalence of HIV among blood donors. Mumtaz et al(8) noted lower seroprevalence of $0.0 \%$ and higher seroprevalence of $3.8 \%$ and $11.7 \%$ have been reported by Matee et al(9) and Dessie et al.(10)

Our study showed higher seropositivity rates of transfusion transmitted infections like HIV in replacement donors compared to voluntary donors, a similar finding was noted by Singh et al,(3) Chiavetta et al(11) and Makroo et al.(12)

The present study reported higher prevalence of HIV infection among young men in the age group of 18 - 30 years. Similar finding was noted by Osmond et al.(13)

Our study analysed gender distribution of HIV positive blood donors. According to NACO, more men are HIV positive than women. Higher seropositivity of HIV was found in males in our study. Karmakar et al(14) and Makroo et al(12) also noted higher seropositivity rate in male donors compared to female donors.

Our study analysed demographic distribution of HIV positive blood donors. It was found that higher seropositivity was seen in donors from urban population. Similar findings were noted by Glück et al.(15)

\section{CONCLUSION}

In conclusion, our study showed the prevalence of HIV to be $0.071 \%$ in our tertiary care teaching hospital situated in Hapur, Uttar Pradesh. The seroprevalence was relatively low because of effectiveness of donor screening to exclude donors with a history of high risk behaviour, pre-donation counselling and self-deferral by donors. Our study showed higher seropositivity rates in replacement donors compared to voluntary donors. Hence, the need of the hour is to enhance voluntary donations, create awareness amongst people and build proper health education system.

\section{REFERENCES}

[1] WHO Guidelines of Blood Transfusion Safety Appia, CH-1211 Geneva 27, Switzerland.

[2] Singh B, Verma M, Kotru M, et al. Prevalence of HIV \& VDRL seropositivity in blood donors of Delhi. Indian J Med Res 2005;122(3):234-6.
[3] Singh B, Kataria SP, Gupta R. Infectious markers in blood donors of East Delhi: prevalence and trends. Indian J Pathol Microbiol 2004;47(4):477-9.

[4] Kochhar AK, Singh K, Kochhar SK. A study to assess trend in seroprevalence of hepatitis B virus infection among blood donors of southern Haryana, India. The Internet Journal of Pathology 2012;13(2).

[5] Bani M, Giussani B. Gender differences in giving blood: a review of the literature. Blood Transfus 2010;8(4):278-87.

[6] Gupta N, Kumar V, Kaur A. Seroprevalence of HIV, HBV, HCV, and syphilis in voluntary blood donors. Indian J Med Sci 2004;58(6):255-7.

[7] Tiwari BR, Ghimire P, Karki S, et al. Seroprevalence of human immunodeficiency virus in Nepalese blood donors: a study from three regional blood transfusion services. Asian J Transf Sci 2008;2(2):66-8.

[8] Mumtaz S, Rehman MU, Muzaffar M, et al. Frequency of seropositive blood donors for hepatitis B, C and HIV viruses in railway hospital, Rawalpindi. Pak J Med Res 2002;41(2):19-2.

[9] Matee MI, Magesa PM, Lyamuya EF. Seroprevalence of human immunodeficiency virus, hepatitis B and C viruses and syphilis infections among blood donors at the Muhimbiili National Hospital in Dar es Salam, Tanzania. BMC Public Health 2006;6:21.

[10] Dessie A, Abera B, Wale F. Seroprevalence of major blood borne infections among blood donors at Felege Hiwot referral hospital, Northwest Ethopia. Ethiop J Health Dev 2007;21(1):68-9.

[11] Chiavetta JA, Maki E, Gula CA, et al. Estimated risk of transfusion transmitted infection in the Canadian blood supply (1987-1996). Vox Sang 2000;78(Suppl 1):360.

[12] Makroo RN, Hegde V, Chowdhry M, et al. Seroprevalence of infectious markers \& their trends in blood donors in a hospital based blood bank in north India. Indian J Med Res 2015;142(3):317-22.

[13] Osmond DH, Page K, Wiley J, et al. HIV infection in homosexual and bisexual men 18 to 29 years of age: the San Francisco Young Men's health study. Am J Public Health 1994;84(12):1933-7.

[14] Karmakar PR, Shrivastava P, Ray TG. Seroprevalence of transfusion transmissible infections among blood donors at the blood bank of a Medical College of Kolkata. Indian J Public Health 2014;58(1):61-4.

[15] Glück D, Vornwald A, Gossrau E, et al. HIV prevalence in blood donors in urban and in rural areas of the Federal Republic of Germany. Blut 1990;60(5):3047. 